\title{
Sifat-Sifat Pembakaran Bioetanol Gel Dari Buah Berenuk (Crescentia Cujete L.)
}

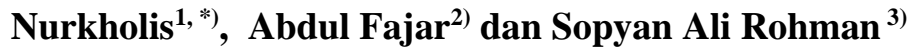 \\ 1,2 Fakultas Teknologi Pertanian, Program Studi Teknologi Industri Pertanian \\ Universitas Teknologi Sumbawa \\ ${ }^{3}$ Fakultas Teknik, Program Studi Teknik Mesin \\ Universitas Teknologi Sumbawa \\ *) Corresponding author: nurkholis@uts.ac.id \\ ((Received 31-Oct-19 • Revised 18-Nov-19 • Accepted 29-Nov-2019)
}

\begin{abstract}
One of the potential sources of biofuels is, for example, berenuk (Crescentia cujete L.), because it has a fairly high carbohydrate content of $15.56 \%$ (wet basis) and $68.13 \%$ (dry basis). Liquid bioethanol can be converted into a gel by the addition of a thickener used, which is chosen because it has economic value, for example, carboxymethyl cellulose (CMC). This study aims to know the properties of ethanol gel combustion from berenuk (Crescentia cujete L.) using carboxymethyl cellulose (CMC) thickener produced, such as: heating value, and combustion test (combustion rate, flame and residue of combustion results), so that it can be known the best formulation to produce ethanol gel. Bioethanol gel production is carried out by a gelation process that is by mixing 1, 2, and 3-gram carboxymethyl cellulose (CMC) thickener with $20 \mathrm{~mL}$ aqua dest, and liquid bioethanol as much as $100 \mathrm{~g}$ with stirring using magnetic stirrer for 15 minutes at $600 \mathrm{rpm}$ speed of $600 \mathrm{rpm}$. The results showed that the best combustion properties were variations in carboxymethyl cellulose (CMC) weight of 3 grams with a calorific value of 2,334 call gram, combustion rate of 0.0369 grams/ second and combustion residue ranged from $45-47 \%$.
\end{abstract}

\begin{abstract}
Abstrak
Salah satu sumber bahan bakar nabati yang berpotensi misalnya adalah buah berenuk (crescentia cujete L.), karena mempunyai kandungan karbohidrat yang cukup tinggi yaitu 15,56\% (wet basis) dan $68,13 \%$ (dry basis). Bioetanol cair dapat diubah menjadi gel dengan penambahan pengental yang mempunyai nilai ekonomis, misalnya carboxymethyl cellulose (CMC). Penelitian ini bertujuan untuk mengetahui sifat-sifat pembakaran gel etanol dari buah berenuk (crescentia cujete L.) menggunakan bahan pengental CMC yang dihasilkan, seperti: nilai kalor, dan uji pembakaran (laju pembakaran, nyala api dan residu hasil pembakaran), sehingga dapat diketahui formulasi terbaik untuk menghasilkan gel etanol. Pembuatan gel bioetanol dilakukan proses gelasi yaitu dengan mencampurkan bahan pengental CMC sebanyak 1, 2, dan 3 gram dengan $20 \mathrm{~mL}$ akuades, dan bioetanol cair sebanyak $100 \mathrm{~g}$ sedikit demi sedikit dengan pengadukan menggunakan magnetic stirrer selama 15 menit dengan kecepatan $600 \mathrm{rpm}$. Hasil penelitian menunjukkan bahwa sifat-sifat pembakaran terbaik adalah pada variasi berat (CMC) sebesar 3 gram dengan nilai kalor sebesar 2.334 $\mathrm{kal} /$ gram, laju pembakaran 0,0369 gram/ detik dan residu pembakaran berkisar antara 45-47\%.
\end{abstract}

Keywords: bioetanol gel, buah berenuk, carboxymethyl cellulose, sifat-sifat pembakaran 


\section{PENDAHULUAN}

Konsumsi bahan bakar pada berbagai sektor kehidupan sangatlah mempengaruhi ketersediaan bahan bakar fosil yang semakin menipis. Hal ini menyebabkan terjadinya kelangkaan bahan bakar di masa depan, dan menuntut diversifikasi bahan bakar yang lebih bersih dan bersifat renewable. Salah satu bahan bakar alternatif berbasis bahan nabati yang dikenal masyarakat yaitu bioetanol cair. Bioetanol merupakan salah satu energi alternatif yang mempunyai beberapa kelebihan, misalnya dapat diperbarui dan ramah lingkungan (emisi $\mathrm{CO}_{2}$ rendah) [1]. Sumber bahan bakar nabati yang berpotensi misalnya adalah buah berenuk (crescentia cujete L.). Selama ini pemanfaatan buah berenuk belum optimal dikarenakan kurangnya pengetahuan masyarakat akan potensi buah berenuk. Kandungan karbohidrat dalam buah berenuk cukup tinggi yaitu 15,56\% (wet basis) dan 68,13\% (dry basis), sehingga dapat dikonversi sebagai bioetanol [2].

Bioetanol cair beresiko tumpah dan bersifat eksplosif karena mudah menguap atau volatil saat didistribusikan [3]. Sehingga, untuk meminimalisir bahaya tersebut bioetanol perlu dimodifikasi dalam bentuk gel. $\mathrm{Gel}$ adalah sistem padat atau setengah padat dan terdiri dari konstituen padat dan cairan. Gel terdiri dari dua fase kontinyu yang saling berpenetrasi, yaitu padatan yang tersusun dari partikel-partikel yang tidak simetris dengan luas permukaan besar, dan cairan [4].

Menurut [5], gel bioetanol tidak menghasilkan asap selama pembakaran, tidak menghasilkan jelaga, gas berbahaya, tidak karsinogenik dan tidak korosif. Bioetanol dapat diubah menjadi gel dengan menambahkan bahan pengental. Hal ini menyebabkan bioetanol tidak mudah menguap karena terserap ke dalam bahan pengental yang akan menahan laju penguapannya. Bioetanol gel memiliki beberapa kelebihan dibanding bahan bakar padat briket maupun parafin yaitu bersifat terbarukan, tidak menghasilkan asap, tidak menimbulkan jelaga. Selain itu, bentuk gel dari bioetanol ini memudahkan dalam pengemasan dan juga pendistribusian [6].

Pada pembuatan bioetanol gel dibutuhkan kalsium asetat atau pengental lainnya seperti xanthan gum, karbopol dan berbagai material turunan selulosa seperti carboxymethyl cellulose (CMC) [7]. Bahan pengental yang digunakan dipilih yang mempunyai nilai ekonomis. Selain itu, bahan pengental yang dipilih adalah bahan pengental yang mempunyai sifat dapat larut. Menurut [8], CMC mempunyai karakteristik yang larut sebagian pada campuran larutan etanol dan air, sehingga dapat digunakan sebagai bahan pengental dalam pada komposisi tertentu. Selain itu, CMC dapat merubah fisik etanol cair menjadi gel dan bisa terbakar. CMC merupakan salah satu bahan pengental turunan selulosa yang berfungsi sebagai stabilizer, thickening agent dan emulsifier pada makanan. CMC dapat larut di dalam air dan menghasilkan larutan yang jernih, tanpa warna dan bau. Sifat CMC yang biodegradable dan food grade relatif aman untuk digunakan dalam aplikasi gel bioetanol sebagai bahan bakar rumah tangga alternatif [9].

Penggunaan CMC di Indonesia sebagai bahan penstabil, pengental, dan pembentuk gel dalam produk pangan, diatur menurut PP. No. 235/ MENKES/ PER/ VI/ 1979 adalah 1-2\%, sehingga dalam penelitian ini digunakan variasi CMC sebanyak 1, 2 dan 3 gram. Selain itu, penggunaan bahan pengental yang berlebihan dapat menyebabkan efek pada tekstur serta penampakan hasilnya akan menjadi kasar dan menggumpal.

Pada penelitian sebelumnya yang telah dilakukan [10], pembuatan gel bio-etanol menggunakan bahan pengental CMC dengan variabel kadar etanol yaitu 70, 80 dan 90\% dan CMC sebesar 1,2, 1,5 dan 1,8 gram. Hasil penelitian menunjukkan bahwa etanol 90\% dengan bahan pengental carboxymethyl cellulose (CMC) sebesar 1.5 gram menunjukkan hasil nilai 
kalor sebesar $12.382 \mathrm{~J} / \mathrm{gr}$, dan residu pembakaran sebesar 29,44\%. Pada penelitian yang lain yang dilakukan oleh [9]. Kajian produksi gel bioetanol dengan menggunakan CMC sebagai bahan pengental dengan variabel kadar bioetanol sebesar 55\%, 65\%, 75\%, dan CMC sebesar 0,75 , 1, dan 1,25 gram. Hasil penelitian menunjukkan bahwa semakin banyak bahan pengental yang ditambahkan maka nilai kalornya akan semakin tinggi seperti terlihat pada hasil pengujian dengan menggunakan etanol $65 \%$ dan CMC sebesar 1,25\% menunjukkan hasil nilai kalor sebesar $15.83 \mathrm{MJ} / \mathrm{kg}$.

Berdasarkan beberapa penelitian tersebut, penelitian ini bertujuan untuk menghasilkan sifat-sifat pembakaran gel etanol dari buah berenuk (crescentia cujete L.) menggunakan bahan pengental CMC yang dihasilkan, seperti: nilai kalor, dan uji pembakaran (laju pembakaran, nyala api dan residu hasil pembakaran) sehingga dapat diketahui formulasi terbaik untuk menghasilkan gel etanol.

\section{METODE PENELITIAN}

\section{Bahan dan Alat Penelitian}

Bahan utama yang digunakan dalam penelitian ini adalah bioetanol gel dari daging buah berenuk dan bahan pengental yaitu CMC.

Alat yang digunakan dalam penelitian ini meliputi: magnetic stirrer, termometer, neraca digital, gelas beaker, cawan porselen, kalorimeter bom, desikator dan stopwatch.

\section{Prosedur Penelitian}

Prosedur pembuatan gel bioetanol merupakan modifikasi dari prosedur penelitian [9], yaitu bahan pengental CMC sebanyak 1, 2, dan 3 gram dicampur terlebih dahulu dengan 20 $\mathrm{mL}$ akuades. Campuran tersebut diaduk selama 5 menit, kemudian ditambahkan bioetanol cair sebanyak $100 \mathrm{~g}$ sedikit demi sedikit sambil diaduk dengan magnetic stirrer selama 15 menit dengan kecepatan $600 \mathrm{rpm}$. Selanjutnya bioetanol gel diuji nilai kalor, dan uji pembakaran (laju pembakaran, nyala api dan residu hasil pembakaran).

\section{Analisis Hasil}

\section{Nilai Kalor}

Nilai kalor atau nilai energi adalah hasil pembakaran sempurna satu kilogram atau satu satuan bahan bakar atau satu satuan volume. Nilai kalor diukur dengan menggunakan alat Bomb Calorimeter merk IKA [9].

\section{Uji Pembakaran}

Uji pembakaran dilakukan untuk mengetahui efisiensi pembakaran bioetanol gel, dilihat dari laju pembakaran dan residu hasil pembakaran. Untuk mengetahui laju pembakaran bioetanol gel, sampel dengan ukuran tertentu dibakar dan apinya dibiarkan menyala hingga padam. [10]. 


\section{HASIL DAN PEMBAHASAN}

\section{Nilai Kalor}

Nilai kalor berhubungan erat dengan komposisi karbon terikat pada suatu bahan bakar. Semakin tinggi karbon terikat yang dimiliki, maka nilai kalornya juga semakin tinggi. Hal ini disebabkan dalam pembakaran dibutuhkan karbon yang bereaksi dengan oksigen untuk menghasilkan kalor [12]. Perbandingan nilai kalor dari masing-masing jenis konsentrasi bioetanol gel yang dilakukan pengujian dapat dilihat pada Gambar 1.

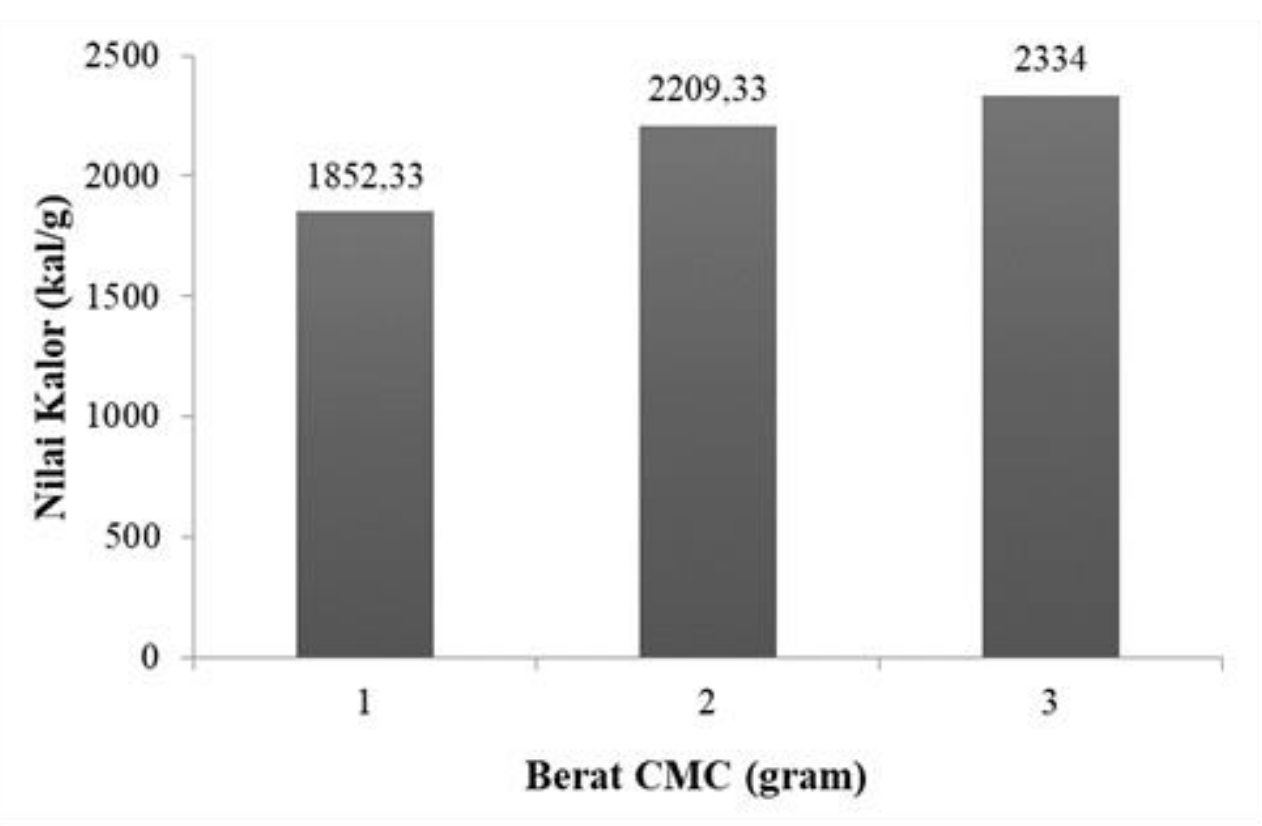

Gambar 1. Perbandingan Nilai Kalor

Dari Gambar 1 di atas dapat terlihat nilai kalor tertinggi dan terendah pada masing masing bioetanol gel. Nilai kalor tertinggi terdapat pada CMC sebanyak 3 gram pada $50 \mathrm{~mL}$ bioetanol dengan nilai kalor sebesar $2.334 \mathrm{kal} / \mathrm{gram}$, sedangkan nilai kalor terendah terdapat pada konsentrasi 1 gram CMC pada $50 \mathrm{~mL}$ bioetanol dengan nilai kalor sebesar 1.852,33 $\mathrm{kal} / \mathrm{gram}$. Dari hasil penelitian diatas menunjukkan bahwa semakin banyak jumlah CMC yang dicampur dengan bioetanol cair dalam pembuatan bioetanol gel, maka semakin tinggi pula nilai kalor yang dihasilkan. Nilai kalor yang dihasilkan pada penelitian sedikit lebih rendah dari penelitian yang dilakukan oleh [10]. Hal ini terjadi karena pada penelitian ini, etanol yang digunakan merupakan etanol yang dihasilkan dari buah berenuk dengan kemurnian yang relatif rendah.

Nilai kalor ini memiliki hubungan erat dengan nilai kadar air yang terdapat pada bioetanol gel. Tinggi dan rendahnya nilai kalor sangat dipengaruhi oleh kadar air. Semakin rendah kadar air maka nilai kalor yang dihasilkan akan semakin tinggi, dan semakin tinggi nilai kadar air yang terdapat pada bioetanol gel maka semakin rendah nilai kalor yang akan dihasilkan. Hal ini sesuai dengan hasil penelitian yang dilakukan oleh [12], yang mengatakan bahwa nilai kalor bahan bakar bioetanol gel berhubungan dengan nilai kadar air yang terdapat pada bioetanol gel tersebut, semakin rendah kadar air maka akan menghasilkan nilai kalor yang semakin tinggi, sedangkan semakin tinggi nilai kadar air, maka akan meperoleh nilai kalor yang semakin rendah. Selain itu, faktor lain yang dapat mempengaruh terhadap tinggi 
rendahnya nilai kalor adalah kandungan carbon dan oxygen. Dari hasil pengujian nilai kalor di atas menunjukkan bahwa semakin banyak jumlah CMC yang ditambahkan pada bioetanol cair dari buah berenuk dalam pembuatan bioetanol gel, maka semakin tinggi pula nilai kalor yang dihasilkan.

\section{Uji Pembakaran}

Uji pembakaran dilakukan dengan tujuan untuk mengetahui seberapa efisien bioetanol gel dari buah berenuk dapat terbakar. Laju pembakaran dan residu pembakaran menunjukkan seberapa cepat suatu bahan terbakar dan seberapa banyak residu atau sisa hasil pembakaran bahan yang tidak terbakar habis dalam proses pembakaran [13]. Menurut [14] mengatakan bahwa laju pembakaran bergantung pada kemudahan bahan untuk terbakar. Bioetanol merupakan salah satu bahan yang mudah terbakar. Hasil pengujian laju pembakaran dari masing-masing jenis konsentrasi bioetanol gel dapat dilihat pada Gambar.

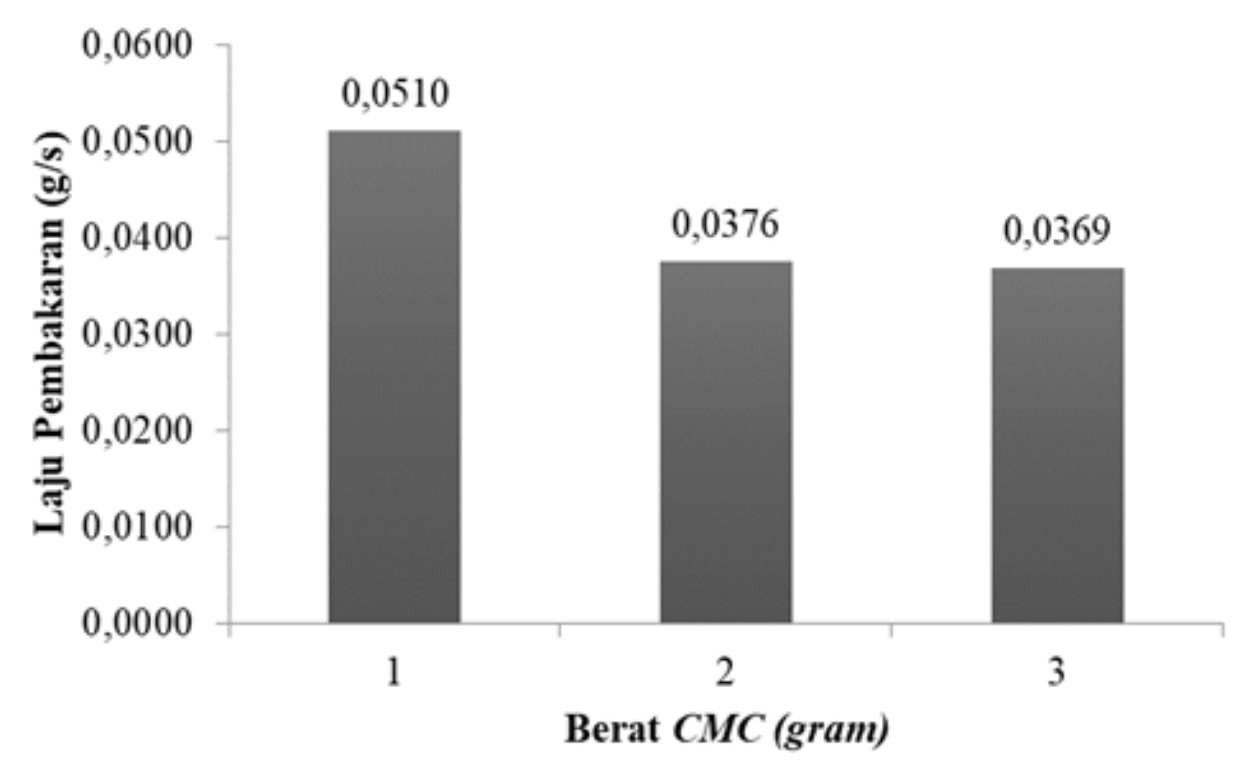

Gambar 2. Perbandingan Laju Pembakaran

Dari Gambar 2 di atas menunjukkan laju pembakaran pada masing-masing konsentrasi bioetanol gel buah berenuk. Laju pembakaran tertinggi berada pada bioetanol gel dengan berat 1 gram CMC sebesar 0,0510 gram/ detik, sedangkan laju pembakaran terendah diperoleh pada bioetanol gel dengan konsentrasi 3 gram CMC yaitu 0,0369 gram/ detik.

Semakin banyak CMC pada bioetanol gel akan memperkecil laju pembakaran, dan semakin sedikit CMC akan semakin besar laju pembakaran pada bioetanol gel. Dari penjelasan di atas sesuai dengan penelitian yang telah dilakukan oleh [13], menjelaskan bahwa adanya bahan pengental menjadi faktor penahan agar laju pembakaran menjadi semakin panjang. Bahan pengental dengan konsentrasi yang semakin meningkat akan menahan laju penguapan bioetanol karena bioetanol terperangkap di dalam bahan pengental sehingga pelepasan uap bioetanol terjadi secara perlahan. Akibatnya adalah laju pembakaran menjadi semakin panjang, oleh karena itu semakin banyak bahan pengental yang ditambahkan maka lama pembakaran menjadi lebih panjang.

Menurut [15], menjelaskan bahwa penambahan bahan pengental akan mengubah sifat fisik bioetanol sehingga tidak mudah menguap dan bioetanol terserap di dalam bahan pengental 
yang akan menahan laju penguapannya, hal ini juga berpengaruh pada saat pembabakarannya. Dimana penambahan bahan pengental yang semakin tinggi akan mengurangi laju pembakarannya sehingga efektifitas penggunananya akan semakin bagus karena bahan bakar bioetanol gel akan lebih irit dengan proses pembakaran yang semakin lama.

Selanjutnya uji pembakaran bioetanol gel yang dilakukan menghasilkan sisa pembakaran yang merupakan residu pembakaran yang tidak dapat terbakar saat proses pembakaran dilakukan. Sisa hasil pembakaran mengindikasikan seberapa banyak sampel yang terbakar. Semakin sedikit residu yang dihasilkan maka semakin banyak sampel yang terbakar [14]. Hasil perbandingan residu pembakaran dari masing-masing jenis konsentrasi bioetanol gel yang dilakukan pengujian dapat dilihat pada Gambar 3.

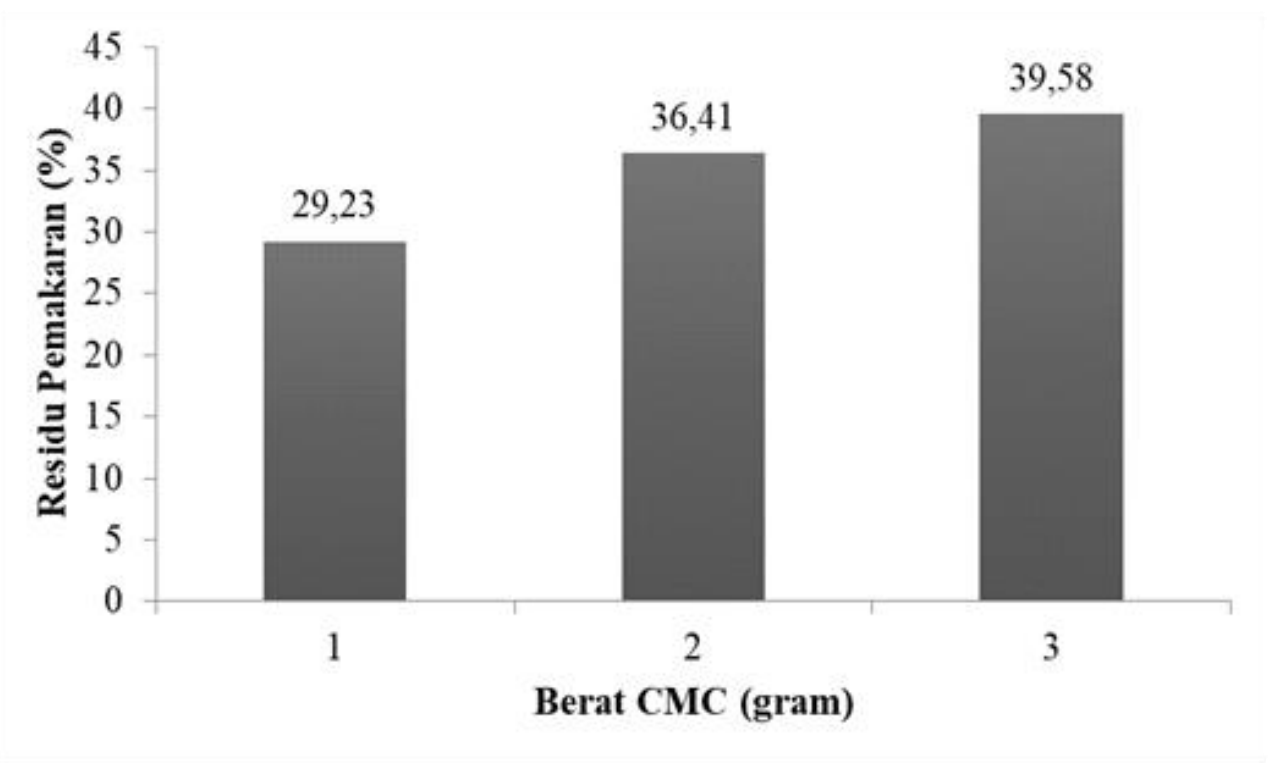

Gambar 3. Perbandingan Residu Pembakaran

Dari Gambar 3 di atas dapat terlihat bahwa residu pembakaran terus meningkat seiring meningkatnya berat CMC yang ditambahkan pada masing-masing bioetanol gel. Residu pembakaran terbanyak dihasilkan pada bioetanol gel dengan penambahan CMC sebanyak 3 gram yaitu 39,58\%, sedangkan residu pembakaran terendah terdapat pada bioetanol gel dengan CMC 1 gram sebesar 29,23\%.

Tingginya sisa pembakaran atau residu pembakaran yang dihasilkan karena masih rendahnya kadar etanol dan masih banyaknya kandungan air yang terdapat pada bioetanol gel tersebut. Selain itu, peningkatan residu pembakaran yang terjadi seiring dengan peningkatan konsentrasi bahan pengental disebabkan karena sifat kimia CMC yang tidak terbakar habis pada saat dilakukan pembakaran sehingga menimbulkan residu pembakaran tersebut.

Hal ini sesuai dengan penelitian yang dilakukan oleh [9], yang mengatakan bahwa semakin sedikit jumlah CMC dan semakin tinggi konsentrasi bioetanol, semakin sedikit residu pembakaran yang terbentuk. Dalam penelitiannya menjelaskan residu pembakaran yang berjumlah paling banyak terdapat pada konsentrasi bioetanol 55\%. Pada konsentrasi bioetanol 55\%, residu pembakaran berkisar antara 45-47\% karena $45 \%$ dari gel bioetanol adalah air yang berikatan dengan CMC dan tidak habis terbakar dan tertinggal sebagai residu hasil pembakaran. Residu pembakaran yang dihasilkan pada penelitian ini sedikit lebih banyak dari penelitian yang dilakukan oleh [10]. Hal ini terjadi karena penelitian ini 
menggunakan CMC sedikit lebih banyak, sehingga residu yang berasal dari CMC yang tidak terbakar juga semakin banyak.

\section{KESIMPULAN}

Sifat-sifat pembakaran (nilai kalor, laju pembakaran dan residu hasil pembakaran) akan semakin optimal dengan semakin banyaknya penambahan bahan pengental CMC. Pada penelitian ini, sifat-sifat pembakaran optimal yang dihasilkan, yaitu: nilai kalor sebesar 2.334 $\mathrm{kal} / \mathrm{gram}$, laju pembakaran 0,0369 gram/detik dan residu pembakaran berkisar antara 29,23$39,58 \%$.

\section{UCAPAN TERIMAKASIH}

Penelitian ini dapat terlaksana dengan baik atas pendanaan dari Hibah Kompetitif Penelitian Dosen Pemula (PDP) dari Kementerian Riset Teknologi dan Pendidikan Tinggi, Indonesia dengan Nomor Kontrak 0949/L8/KM/2019.

\section{DAFTAR PUSTAKA}

[1] M. N. Ogbuagu, "The Nutritive and Anti-Nutritive Compositions of Calabash (Crescentia cujete) Fruit Pulp," Journal of Food Technology, vol. 6, pp. 267-270, 2008.

[2] J. Robinson, "Bio-ethanol as a household cooking fuel: a mini pilot study of the SuperBlu stove in peri-urban Malawi," Loughborough University, Leics, 2006.

[3] A. Martin, J. Swarbrick and A. Cammarata, Physical pharmacy: Physical chemical principles in the pharmaceutical sciences, 3rd ed, Philadelphia: Lea \& Febiger, 1993.

[4] R. E. Merdjan and J. Matione, "Fuel Gas". United State Patent US 2003/0217504A1, 2003.

[5] P. Lloyd and E. F. Visagie, "THE TESTING OF GEL FUELS, AND THEIR COMPARISON TO ALTERNATIVE COOKING FUELS," Journal of Energy in Southern Africa, vol. 18, no. 4, 2007.

[6] L. A. Tambunan, "Bioetanol Antitumpah," Trubus, vol. XXXIX, pp. 24-25, 2008.

[7] A. Desmarais, "Hydroxyalkyl derivatives of cellulose (Chapter XXIX)," in Industrial Gums, 2nd edn, New York, Academic Press, 1973.

[8] A. Riyanti., K. Syamsu and E. G. Sa'id, "Kajian Produksi Gel Bioetanol Dengan Menggunakan Carboxymethylcellulose (CMC) Sebagai Bahan Pengental," Agroindustrial Technology - IPB, Bogor, 2009.

[9] B. Y. Jeon, S. A. Kim, D. H. Kim, B. K. Na, D. H. Park, H. T. Tran, R. Zhang and D. H. Ahn, "Development of a serial bioreactor system for direct ethanol production from starch using Aspergillus niger and Saccharomyces cerevisiae," Biotechnology and Bioprocess Engineering, vol. 12, no. 5, pp. 566-573, 2007. 
[10] A. Nugroho, F. Restuhadi and E. Rossi, "Pembuatan Gel Etanol Dengan Menggunakan Bahan Pengental Carboxymethycellulose (CMC)," Jurnal Online Mahasiswa Bidang Pertanian, vol. 3, no. 1, 2016.

[11] V. Hanun and D. H. Sutjahjo, "Komparasi Karakteristik Bioetanol Gel dengan Pengental Karbopol dan Carboxy Methyl Cellulose (CMC) sebagai Bahan Bakar Alternatif," Jurnal Pendidikan Teknik Mesin, vol. 7, no. 2, pp. 14-20, 2018.

[12] R. D. Tyastando, J. Ardiansah, A. E. Pramudita and D. Riandadari, "Studi Experimental Pembuatan Bioetanol Gel Dengan Pengental CMC dan Pengujian Performance Bioetanol Gel," Indonesian Journal Of Engineering and Technology (INAJET), vol. 1, no. 2, pp. 1-7, 2019.

[13] S. B. Ariyani and N. Supriyatna, "Perbandingan Karbopol dan Carboxymethyl Cellulose Sebagai Pengental Pada Pembuatan Bioetanol Gel," Jurnal Biopropal Industri, vol. 4, no. 2, pp. 59-64, 2013.

[14] D. A. A, H. S and K. V. Dian., "Formulasi Bioetanol gel Padat Dengan Variasi Gelling Agent Sebagai Bahan Bakar Alternatif Ramah Lingkungan," Jurnal Industri Inovatif, vol. 4, no. 2, pp. 13-19, 2014.

[15] Sutarsa, "Pengaruh Formulasi Carboxy Methyil Cellulose dan Asam Stearat Terhadapa Karakteristik Gel Bioetanol," Jurnal Rekayasa dan Manajemen Agroindustri, vol. 5, no. 2, pp. 18-27, 2017. 